\section{PENGELOLAAN PENDIDIKAN MADRASAH ALIYAH: \\ TELAAH TERHADAP PERATURAN MENTERI \\ PENDIDIKAN NASIONAL NO. 19 TAHUN 2007 TENTANG STANDAR PENGELOLAAN PENDIDIKAN}

\section{Yundri Akhyar}

Pusat Bahasa Uin Suska Riau

\section{Abstract}

The Management of Education in Madrasah Aliyah: A Study on The Regulation of Ministry of Education No.19 In 2007 About The Standardization of Management: Nowadays, the management of Madarasah Aliyah is not maximal yet. The quality of its management is still under of SMU. In fact, there is UU SIKDIKNAS eliminating the discrimination between the secular and religious education. This law is explained in PP. NO. 19 in 2005 about the standardization of national education. But it does not improve the quality of $M A$. This regulation is described in a detailed explanation in PP. NO. 19 in 2007 about the standardization of education's management. This clearly explain the management of $M A$, including the implementation of $M A$ 's programs, funding, ethics, supervision, evaluation, leadership of $M A$, and information access. These are done based on independence, partnership, participation, transparency, and accountability. Therefore, the management of $M A$ should be effective and efficient.

Keywords: Education, Madrasah Aliyah, and Unit or Level of Education.

\section{Pendahuluan}

Setiap agama memposisikan dirinya sebagai sebuah tantanan nilai mulia yang menjiwai apapun yang terdapat di dunia ini. Termasuk di dalamnya pendidikan. Ali, ${ }^{1}$ mengatan para penganut Agama Islam, Kristen dan Katolik misalnya. Akhirnya memaksakan integrasi antara

1 Ali Al-Jumbulati, Perbandingan Pendidikan Islam (Jakarta: RajaGrafindo Persada, 1994), hlm. 65
Al-Fikra: Jurnal Ilmiah Keislaman, Vol. 8, No. 2, Juli-Desember 2009 agama dengan pendidikan hingga kepada simbol keagamaan lembagalembaga pendidikan yang mereka kelola. Awal sejarah pendidikan di negeri inipun sebenarnya sudah diawali dengan fenomena itu. Jauh sebelum Indonesia merdeka, mereka telah menyebarkan agama melaalui penyelenggaraan pendidikan.

Agama akhirnya diakomodasi oleh konstitusi Indonesia sebagai bagian yang tak terpisahkan dari sektor pendidikan. Konsekwensinya, semua lembaga pendidikan, termasuk sekolah-sekolah yang dikelola oleh negara pun yang sering kali lebih dituntut untuk menjadi netral tidak bisa dipisahkan dari kelaziman itu. ${ }^{2}$ Pengelolaan pendidikan yang baik sebenarnya adalah pendidikan yang dapat memamfaatkan potensi budaya yang tumbuh dan berkembang di Indonesia yang dihuni oleh bermacam suku, agama, dan adat istiadat yang sangat berbeda satu sama lain, maka seberagam itu pula pola pendidikan yang mereka kembangkan. Atas dasar ini konstitusi Undang-Undang Dasar 1945 dan Undang-Undang Sistem Pendidikan Nasional (SPN) mengamanatkan perlunya penyelenggaraan pendidikan dengan melestarikan keaneka ragaman penyelenggaraan pendidikan di masyarakat, akan tetapi berada dalam satu pengelolaan, bernama Sistem Pendidikan Nasional. ${ }^{3}$

Di dalam sistem ini diharapkan keragaman penyelenggaraan pendidikan bisa melahirkan kekauatan pendidikan yang dahsyat. Keragaman penyelenggaraan pendidikan di Indonesia dapat ditelusuri dalam dua ketegori. Pertama, penyelenggaraan yang dilakukan masyarakat dengan kreaktivitas yang rendah. Misalnya semacam ini sebenarnya cenderung memiliki seragam karena dianggap memudahkan. Keseragaman tersebut antara lain dalam bentuk nomenklatur satuan pendidikan, seragam sekolah, hari masuk dan libur sekolah, sistem penilaian dan sebagainya.

Masalah keseragaman kurikulum, walaupun undang-udang sudah menyuruh agar masing-masing sekolah menyusun sendiri

\footnotetext{
2 Ibid., hlm. 67

3 Tilaar, Paradigma Baru Pendidikan Nasional (Jakarta: Rineka Cipta, 2004), hlm.
} 34 
Yundri Akhyar, Pengelolaan Pendidikan Madrasah Aliyah ...

kurikulumnya mereka lebih suka menggunakan kurikulum yang dikeluarkan oleh pemerintah. Bahkan pada tingkat silabus pun (rencana pelaksanaan pelajaran) mereka lebih suka menggunakan paket yang sudah jadi dari pemerintah. Kategori kedua terdapat pada masyarakat yang memeliki tingkat kreaktivitas yang cukup tinggi (yang ini miniritas). Mereka cenderung menyebut pemerintah sampai saat ini mengatur pendidikan hingga hal-hal yang seharusnya diatur oleh sekolah sendiri. Terutama sekolah-sekolah swasta, banyak sekali sekolah yang menginginkan pemerintah cukup mengatur hasil pendidikan saja. Proses penyelenggaraan pendidikan tidak usah diatur. ${ }^{4}$

Standar Pendidikan Nasional yang diamanatkan Undang-Undang 20 Tahun 2003 akhirnya melahirkan sebuah badan baru yang relatif independent bernama Badan Standar Nasional Pendidikan (BSNP). Aturan standarisasi pendidikan kemudian dituangkan secara lebih rinci dalam Peraturan Pemerintah Nomor 19 Tahun 2005 tentang Standar Nasional Pendidikan (SNP). Dengan Standar Nasional Pendidikan ini, semua jenis pendidikan yang selama ini tidak diakui persamaannya dengan pendidikan umum formal, dapat diakui sepanjang persyaratan standar minimal dipenuhi. satu persatu pendidikan tradisional pun kini mulai gembira karena akan memiliki hak yang tidak jauh beda dari sekolah biasa yang dianak emaskan pemerintah. ${ }^{5}$

Pengalaman pendidikan Islam di Indonesia sebagai pendidikan bebasis masyarakat menunjukkan bahwa proses akulturasi budaya pendidikan Islam ke dalam sistem pendidikan nasional ternyata tidak terjadi dalam satu tahap secara mudah. Akan tetapi berjalan secara bertahap yang sering kali menemukan kesulitan. ${ }^{6}$

Sejarah pendidikan Islam di Indonesia mula-mula hanyalah pendidikan keagamaan untuk penyebaran agama. Ketika zaman

${ }^{4}$ Depag RI, Pendidikan Islam dan Pendidikan Nasional, Paradigma Baru (Jakarta: Dirjen Binbaga, 2005), hlm. 10-11

${ }^{5}$ Ibid., hlm. 14 hlm. 99

${ }^{6}$ Malik Fadjar, Madrasab dan Tantangan Modernitas (Bandung: Mizan, 1998),
A1-Fikra: Jurnal Ilmiah Keislaman, Vol. 8, No. 2, Juli-Desember 2009

penjajahan datang, terjadi politik pendidikan diskriminatif karena pemerintah penjajah memandang rendah pendidikan pribumi. Kondisi itu baru berubah setelah umat Islam mengembangkan sekolah umum. Termasuk ketika dalam tradisi pendidikan Islam tumbuh tradisi madrasah.

Madrasah berkembang di Indonesia pada abad 20 dengan konotasi madrasah di timur tengah pada masa modern, yang sudah mengajarkan baik ilmu-ilmu agama maupun ilmu umum. Muhamaimin mengatakan sebelum abad 20 tradisi pendidikan Islam di Indonesia agaknya tidak mengenal istilah madrasah, melainkan pengajian alQur`an, masjid, pesantren, surau dan langgar yang dalam sistem pendidikannya tidak dilakukan pengkelasan secara modern tetapi dalam prakteknya tetap adanya perkembangan yang biasanya diatur berdasarkan tingkatan kitab yang diajarkan. ${ }^{7}$

Maksum mengatakan kehadiran madrasah sebagai lembaga pendidikan Islam setidak-tidaknya mempunyai empat latar belakang yaitu : pertama, sebagai manipestasi dan realisasi pembaharuan sistem pendidikan Islam. Kedua, usaha penyempurnaan terhadap system pesantren ke arah suatu system pendidikan yang telah memungkinkan lulusannya untuk memperoleh kesempatan yang sama dengan sekolah umum, misalnya masalah kesamaan, kesempatan kerja dan perolehan ijazah. Ketiga, adanya sikap mental sebagian golongan umat Islam, khususnya santri yang terpukau terhadap pendidikan yang bernuangsa Barat. Keempat, sebagai upaya menjembatani antara sistem pendidikan tradisional yang dilakukan oleh pesantren dan sistem pendidikan modern. ${ }^{8}$

Terlepas dari kenyataan di atas, eksistensi madrasah dalam tradisi pendidikan Islam di Indonesia tergolong penomena modern, sebab buku-buku sejarah pendidikan Islam di Indonesia sejauh ini agaknya tidak pernah menginformasikan adanya lembaga pendidikan yang

7 Muhaimin, Abd Mujib, Pemikiran Pendidikan Islam (Bandung: Trigenda Karya, 1993), hlm. 305

8 Maksum, Madrasah Sejarah \& Perkembangannya (Jakarta: Logos Wacana Ilmu, 1999), hlm. 79 
Yundri Akhyar, Pengelolaan Pendidikan Madrasah Aliyah ...

disebut madrasah pada masa awal penyebaran dan perkembangan Islam di Nusantara. Evolusi kelembagaan pendidikan di masa ini pada umumnya bermula dari pesantren, surau dan sekolah. Dengan demikian A. Mustafa ${ }^{9}$ mengatakan madrasah di Indonesia merupakan sebagai perkembangan lanjut atau pembaharuan lembaga pendidikan pesantren dan surau.

Pada masa awal pemerintahan Orde Reformasi pendidikan madrasah sudah mulai dipandang sebagai Sistem Pendidikan Nasional tetapi merupakan lembaga otonom di bawah pengawasan Mentri Agama. Hal ini disebabkan alasan bahwa sistem pendidikan madrasah lebih didominasi oleh muatan agama. Memang telah menggunakan krikulum standar, tetapi belum seragam dan masih melakukan manajemen yang kurang dapat dikontrol pemerintah. ${ }^{10}$

Memasuki dekade 2000 kebijakan pemerintah Orde Reformasi mengenai madrasah ditunjukkan secara penuh untuk membangun satu sistem pendidikan nasional yang utuh dalam artian pendidikan nasional tidak hanya bergantung pada pendidikan jalur sekolah tetapi juga dimamfaatkan jalur diluar sekolah. ${ }^{11}$

Dalam satu sistem pendidikan, pemerintah mempunyai daya untuk mengawasi dan membina pendidikan yang diselenggarakan oleh siapa pun di negeri ini, maka pemerintah bertanggung jawab untuk membinanya agar sesuai dengan tujuan nasional yang diamanatkan oleh Undang-Undang Nomor 20 Tahun 2003. yang menetapkan adanya kesamaan hak antara pendidikan di sekolah umum dengan madrasah bahkan sekolah-sekolah tradisional. Kemudian UU tersebut ditafsirkan ke dalam Peraturan Pemerintah Nomor 19 Tahun 2005 tentang Standar Nasional Pendidikan. Lalu PP ini ditafsirkan lebih rinci dan jelas oleh beberapa Permendinas. Khusus mengenai

9 Mustafa, Abdullah Aly, Sejarah Pendidikan Islam di Indonesia (Bandung: Pustaka Setia, 1997), hlm. 110

${ }^{10}$ Maksum, Madrasah Sejarah, hlm. 98

11 Depag RI, Sejarah Pendidikan Islam di Indonesia (Jakarta: Dirjen Binbaga, 1986), hlm. 97
Al-Fikra: Jurnal Ilmiah Keislaman, Vol. 8, No. 2, Juli-Desember 2009 pengelolaan pendidikan madrasah dijelaskan oleh Permendinas no. 19 tahun 2007 tentang Standar Pengelolaan Pendidikan.

\section{Pengertian Madrasah}

Kata "madrasah" dalam bahasa Arab adalah bentuk kata "kererangan tempat" (zharaf makan) dari akar kata "darasa". Secara harfiah "madrasah" diartikan sebagai "tempat belajar para pelajar" atau "tempat untuk memberikan pelajaran".12 Dari akar kata "darasa" juga dapat diturunkan kata "madras" yang mempunyai arti "buku yang dipelajari" atau "tempat belajar" kata "al-Midras" juga diartikan sebagai "rumah untuk mempelajari kitab Taurat".13

Malik Fadjar mengatakan jika diterjemahkan ke dalam bahasa Indonesia, kata "madarasah" memiliki arti sekolah. Sungguhpun secara teknis, yakni dalam proses belajar-mengajarnya secara formal, madrasah tidak berbeda dengan sekolah, namun di Indonesia madrasah tidak lantas difahami sebagai sekolah, melainkan diberi konotasi yang lebih spesifik lagi, yakni "sekolah agama". Tempat dimana anak-anak didik memperoleh pembelajaran hal-ihwal atau seluk beluk-beluk agama Islam. ${ }^{14}$

Madrasah di Indonesia berbeda dengan madrasah di masa klasik Islam. Mehdi Nakosteen mengatakan di masa klasik Islam, pengertian madrasah (bahasa Arab) merujuk pada lembaga pendidikan tinggi. Sedangkan di Indonesia saat ini makna madrasah telah bergeser menjadi lembaga pendidikan tingkat dasar dan menengah. ${ }^{15}$

Kebanyakan madrasah di Indonesia pada mulanya tumbuh dan berkembang atas inisiatif tokoh masyarakat yang peduli, terutama para ulama yang membawa gagasan pembaharuan pendidikan, setelah mereka kembali dari menuntut ilmu di Timur Tengah. Dana

12 Mehdi Nakosteen, Konstribusi Islam atas Dunia Intelektual Barat: Deskripsi Analisis Abad Keemasan Islam (Surabaya: Risalah Gusti, Edisi Indonesia, 1996), hlm.

13 Abu Luwis, al-Yusu i, al-Munjid Fi al-Lughah Wa al-Mujid Fi al-'Alam (Bairut: Dar al Musyriq, 1998), hlm. 221

14. Malik Fadjar, Madrasah dan Tantangan,, hlm. 111

15 Mehdi Nakosteenm, Konstribusi Islam., hlm. 67 
Yundri Akhyar, Pengelolaan Pendidikan Madrasah Aliyah ...

pembangunan dan pendidikannya pun berasal dari swadaya masyarakat. Karena inisiatif dan dananya didukung oleh masyarakat, maka masyarakat sendiri diuntungkan secara ekonomis, artinya mereka dapat memasukkan anak-anak mereka ke madrasah dengan biaya ringan. ${ }^{16}$

Menurut A. Malik Fadjar, sebagai lembaga pendidikan swadaya, madrasah menampun aspirasi social-budaya-agama masyarakat yang tinggal diwilayah pedesaan. Tumbuh dan berkembangnya madrasah di pedesaan itu menjadi petunjuk bahwa masyarakat Indonesia ternyata memiliki komitmen yang sangat tinggi terhadap pendidikan putra-putri mereka. ${ }^{17}$

Masalah upaya mengembangkan ilmu pengetahuan dan pendidikan umum di madrasah sejak awal perkembangannya di masa klasik Islam telah mengalami kegagalan. Sebab, penekanan pada ilmuilmu agama (al-ulum ad-diniyyah), terutama pada bidang fikih, tafsir, dan hadits, ternyata lebih dominati, sehingga ilmu-ilmu non-agama khususnya ilmu-ilmu alam dan eksakta, tetap berada dalam posisi pinggiran atau marjinal. Menurut A. Malik Fadjar hal ini berbeda dengan madrasah di Indonesia yang sejak awal pertumbuhannya telah dengan sadar menjatuhkan pilihan terhadap salah satu dari dua pilihan, yaitu : pertama, madrasah yang dirikan sebagai lembaga pendidikan yang semata-mata untuk mendalami agama (li tafaqquh fi ad-ddin), yang biasa disebut madrasah diniyah salafiyah. Kedua, madrasah yang didirikan tidak hanya untuk mengajarkan ilmu pengetahuan dan nilainilai Islam, tetapi juga memasukkan pelajaran yang diajarkan di sekolah-sekolah yang diselenggarakan pemerintah Hindia Belanda, seperti madrasah Adabiyah di Sumatera Barat, dan madrasah yang diselenggarakan oleh Muhammadiyah, Persatuan Islam, dan PUI di Majalengka. ${ }^{18}$

16. Rusli Karim, Pendidikan Islam di Indonesia dalam Transformasi Sosial Budaya, (Yogyakarta: Tiara Wacana, 1991), hlm. 163

17. Malik Fadjar, Madrasah dan Tantangan, hlm. 110

18 Ibid., hlm. 111
A1-Fikra: Jurnal Ilmiah Keislaman, Vol. 8, No. 2, Juli-Desember 2009

Dari keterangan diatas menarik untuk dicatat bahwa salah satu karakteristik madrasah yang cukup penting di Indonesia pada awal pertumbuhannya ialah bahwa di dalamnya tidak ada komplik atau upaya mempertentangkan ilmu-ilmu agama dengan ilmu-ilmu umum. Komplik hanya biasa terjadi antara satu organisasi keagamaan dengan organisasi keagamaan lain yang memiliki faham keagamaan yang berbeda, dan mereka sama-sama mendirikan madrasah, misalnya NU, Muhammadiyah, Persis dan lain-lain, memiliki madrasahnya sendirisendiri untuk mensosialisasikan dan mengembangkan faham keagamaan mereka masing-masing.

Kemudian dalam perkembangan selanjutnya pembinaan madrasah diperhatikan pemerintah baik dalam penjenjangan, materi kurikulum, maupun sistem penyelenggaraannya. Dalam pembinaan yang lebih intensif terhadap madrasah ini pemerintah mendirikan madrasah-madrasah negeri. Tujuan penegerian madrasah adalah untuk manjadi model dan standar dalam rangka memberikan ketentuan secara lebih kongkrik bagi penyelenggara madrasah. ${ }^{19}$

Dengan kata lain, pihak-pihak penyelenggara madrasah diharapkan dapat mencontoh dan mempedomani ketentuan-ketentuan penyelenggaraan madrasah; dan demikian diharapkan akan tercapai keseragaman mutu dan kualitas madrasah. Selain itu, madrasahmadrasah negeri dapat menjadi coordinator dalam pelaksanaan evaluasi serta pembinaan terhadap madrasah-madrasah swasta. Dengan adanya proses penegerian ini, keberadaan kelembagaan madrasah selanjutnya mulai betul-betul diperhatikan oleh pemerintah, madrasah yang dibawah kelolaan pemerintah maupun madrasah yang dikelolah swasta

\section{Madrasah Aliyah}

Dengan mengacu pada Peraturan Menteri Agama No. 7 tahun 1952 yang berlaku untuk seluruh wilayah RI, pemerintah menetapkan peraturan yang menyatakan bahwa jenjang pendidikan Madrasah Lanjutan Atas (sekarang Madrasah Aliyah), lama belajar 3 tahun

${ }^{19}$ Depag RI, Sejarah Pendidikan Islam, hlm. 80 
Yundri Akhyar, Pengelolaan Pendidikan Madrasah Aliyah ...

setelah tamat Madrasah Tsanawiyah. ${ }^{20}$ Madrasah Aliyah (MA) ini berada di bawah naungan Depag setara dengan Sekolah Menengah Atas (SMA) yang berada di bawah Diknas. Dari kebijakan pengelolaan walaupun masih ada ksedikit ketimpangan, namun mulai disamakan.

Dengan lahirnya Uu No. 20/2003 Sisdiknas, diperkuat oleh PP No.19/2005 SNP kemudian dijabarkan oleh beberapa Permendinas, maka upaya menjadikan madrasah sebagai "Center of excellence" atau pusat keunggulan sudah saatnya digeirahkan jangan ditunda-tunda lagi; karena madrasah memiliki keunggulan komperatif, yaitu penekanan yang signifikan pada pendidikan agama dan akhlak (moralitas), disamping penekanan pada pendidikan umum berupa pemberian mata pelajaran umum.

\section{Pengelolaan Madrasah Aliyah}

Sebagaimana yang telah penulis jelaskan di sebelumnya bahwa Uu No. 20/2003 Sisdiknas, diperkuat oleh PP No.19/2005 SNP harus mampu menjamin pemerataan kesempatan pendidikan, peningkatan mutu serta relevansi dan efisiensi manajemen pedidikan untuk menghadapi tatangan sesuai dengan tuntutan perubahan kehidupan lokal, nasional, dan global sehingga perlu dilakukan pembaharuan pendidikan secara terencana, terarah dan berkesinambungan.

Upaya peningkatan kualitas pendidikan madrasah mulai menemukan momentumnya ketika Undang-Undang No. 2 Tahun 1989 Tentang Sistem Pendidikan Nasional (UUSPN) ditetapkan. Produk hukum pertama inilah yang menyatakan kesederajatan antara madrasah dengan sekolah. Dengan ditetapkannya undang-undang ini, maka pendidikan madrasah telah diakau sebagai sub-sistem pendidikan nasional. ${ }^{21}$

Sejak adanya undang-undang yang mengatur kesederajatan antara madrasah dengan sekolah, sejak itu pula dualisme sistem pendidikan di tanah air praktis runtuh. Dengan demikian, penarapan undangundang No. 2 tahun 1989 kemudian dikuatkan dengan Uu No.

\section{${ }^{20}$ Ibid.}

${ }^{21}$ Malik Fadjar, Madrasah dan Tantangan, hlm. 67
Al-Fikra: Jurnal Ilmiah Keislaman, Vol. 8, No. 2, Juli-Desember 2009

20/2003 Sisdiknas,merupakan implementasi dari komitmen pemerintah bersama DPR untuk memberdayakan dan meningkatkan mutu pendidikan madrasah.

Lahirnya Uu No. 20/2003 Sisdiknas, disamping untuk merevisi terhadap Uu No. 2/1989 Sisdiknas agar selaras dengan kebijakan pendidikan pemerintah, khususnya kebijakan otonomi daerah, pada sisi lain merupakan "pengukuhan" kembali status madrasah sebagai bagian yang tak terpisahkan dari sistem pendidikan nasional.

Bahkan dalam undang-undang ini, menurut A. Malik Fadjar eksistensi kesederajatan madrasah dengan sekolah semakin kuat dan pengakuan terhadap bentuk-bentuk pendidikan Islam lain, seperti Pondok Pesantren dan Pendidikan Keagamaan semakin ekpilisit. ${ }^{22}$ Bahkan dalam undang-undang ini Departemen Agama di beri peluang baru mendirikan Madrasah Aliyah Ketrampilan sebagai padanan paralel dengan sekolah Menengah Kejuruan yang ada pada Departemen Pendidikan Nasional. ${ }^{23}$ Itu berarti bahwa kehadiran Uu No. 20/2003 Sisdiknas telah membuka peluang yang besar bagi upaya pengembangan institusi pendidikan yang bernama madrasah ini untuk berkembang sejajar dan bahkan berpeluan menjadi bentuk "pendidikan alternatif" bagi masyarakat Indonesia di masa depan.

Dengan keunggulan komperatif yang dimiliki madrasah, yaitu pendidikan moral yang ditawarkannya menjadi daya tarik yang kuat bagi orang tua untuk memasukkan anaknya ke madrasah. Masalahnya sekarang adalah bagaimana lembaga pendidikan yang bernama madrasah ini mempunyai kesiapan untuk memberi pelayanan pendidikan yang diharapkan para orang tua.

Mengistilahkan penyeragaman terhadap hal tertentu sebagai Standarisasi Nasional Pendidikan (SNP). Tujuannya untuk menghasilkan pendidikan yang bermutu dan berdaya saing. SNP dapat digunakan untuk mempertemukan tradisi pendidikan yang berkembang di masyarakat dengan kebijakan negara melalui deal-deal

22 Ibid., hlm. 69

23 Undang-Undang Nomor 20 Tahun 2003 tentang Sistem Pendidikan, Nasional, (Bandung: Fokus Media, 2006), hlm. 45 292 
Yundri Akhyar, Pengelolaan Pendidikan Madrasah Aliyah ...

yang bisa disepakati. Menurut Tilaar, SNP diperlukan agar negara dapat melestarikan keragaman yang menjamin suatu lembaga pendidikan dengan lainnya agar saling bersinergi dan saling melengkapi. ${ }^{24}$

Standar Pendidikan Nasional yang diamanatkan Uu No. 20/2003 Sisdiknas akhirnya melahirkan sebuah badan baru yang relatif independent bernama Badan Standar Nasional Pendidikan (BSNP). Dengan adanya aturan standarisasi pendidikan seperti yang diuraikan dalam Peraturan Pemerintah Nomor 19 tahun 2005 tentang Standar Nasional Pendidikan (SNP), maka semua jenis pendidikan yang selama ini tidak diakui persamaannya dengan pendidikan umum formal, dapat diakui sepanjang persyaratan standar minimal dipenuhi tanpa kecuali pendidikan madrasah. ${ }^{25}$

Dengan lahirnya Peraturan Pemerintah Nomor 19 tahun 2005 tentang Standar Nasional Pendidikan (SNP) ini, maka pengelolaan pendidikan madrasah sudah mendapat titik terang dan mengembirakan walaupun belum begitu maksimal. Standar Nasional Pendidikan ini terdiri atas standar isi, proses, kompetensi lulusan, tenaga kependidikan, sarana dan prasarana, pengelolaan, pembiayaan, dan penilaian pendidikan yang harus ditingkatkan secara berencana dan berkala. Standar nasional pendidikan digunakan sebagai acuan pengembangan kurikulum, tenaga kependidikan, sarana dan prasarana, pengelolaan, dan pembiayaan. ${ }^{26}$ Masing-masing dari kedelepan standar pendidikan tersebut lebih luas dan mendalam dijabarkan oleh Peraturan-paraturan Menteri Pendidikan Nasional.

Khusus mengenai standar pengelolaan Madrasah, ditegaskan dan dijelaskan oleh Peraturan Menteri Pendidikan Nasional Republik Indonesia No 19 Tahun 2007 tentang standar pengelolaan sebagai tafsiran dari Peraturan Pemerintah Nomor 19 tahun 2005 tentang

${ }^{24}$ Tilaar, Paradigma Baru, hlm. 36

${ }^{25}$ Muhaimin, Pemikiran Pendidikan, hlm. 69

26 UU Sisdiknas, hlm. 19
Al-Fikra: Jurnal Ilmiah Keislaman, Vol. 8, No. 2, Juli-Desember 2009

Standar Nasional Pendidikan (SNP) dari pasal 49 sampai pasal 61.27 dalam Peraturan Menteri Pendidikan Nasional tersebut cukup jelas dan rinci mengenai standar pengelolaan pendidikan madrasah mulai dari perencanaan program, pelaksanaan rencana kerja, pengawasan dan evaluasi, kepemimpinan, serta sistem informasi manajemen madrasah aliyah.

\section{Perencanaan Program}

Adapun yang berkaitan dengan perencanaan program Madrasah Aliyah yaitu : Visi, misi, tujuan dan rencana kerja Madrasah Aliyah. Semua ini bisa dilihat pada uraian berikut:

\section{a. Visi Madrasah Aliyah}

Madrasah Aliyah merumuskan dan menetapkan visi serta mengembangkannya. Adapun visi madrasah Aliyah dalam Peraturan Menteri Pendidikan Nasional Republik Indonesia No 19 Tahun 2007 tentang Standar Pengelolaan Pendidikan sebagai berikut : pertama, dijadikan sebagai cita-cita bersama warga MA dan segenap pihak yang berkepentingan pada masa yang akan datang. Kedua, mampu memberikan inspirasi, motivasi, dan kekuatan pada warga MA dan segenap pihak yang berkepentingan. Ketiga, dirumuskan berdasar masukan dari berbagai warga MA dan pihak-pihak yang berkepentingan, selaras dengan visi institusi di atasnya serta visi pendidikan nasional. Keempat, diputuskan oleh rapat dewan pendidik yang dipimpin oleh kepala MA dengan memperhatikan masukan komite MA. Kelima, disosialisasikan kepada warga MA dan segenap pihak yang berkepentingan. Keenam, ditinjau dan dirumuskan kembali secara berkala sesuai dengan perkembangan dan tantangan di masyarakat. ${ }^{28}$

27 Depag, RI. Peraturan Pemerintah No. 19 tahun 2005 tentang Standar Nasional Pendidikan, (Jakarta: Mapenda Islam, 2005), hlm. 28-34

28 Peraturan Menteri Pendidikan Nasional Republik Indonesia No 19 Tahun 2007 tentang Standar Pengelolaan Pendidikan oleh Satuan Pendidikan Dasar dan 294 
Yundri Akhyar, Pengelolaan Pendidikan Madrasah Aliyah ...

b. Misi Madrasah Aliyah

Madrasah Aliyah merumuskan dan menetapkan misi sesua dengan Peraturan Menteri Pendidikan Nasional Republik Indonesia No 19 Tahun 2007 tentang Standar Pengelolaan Pendidikan serta mengembangkannya, sebagai berikut: pertama, memberikan arah dalam mewujudkan visi MA sesuai dengan tujuan pendidikan nasional. Kedua, merupakan tujuan yang akan dicapai dalam kurun waktu tertentu. Ketiga, menjadi dasar program pokok MA. Keempat, menekankan pada kualitas layanan peserta didik dan mutu lulusan yang diharapkan oleh MA. Kelima, memuat pernyataan umum dan khusus yang berkaitan dengan program. Keenam, memberikan keluwesan dan ruang gerak pengembangan kegiatan satuan-satuan unit yang terlibat. Ketujuh, dirumuskan berdasarkan masukan dari segenap pihak yang berkepentingan termasuk komite MA dan diputuskan oleh rapat dewan pendidik yang dipimpin oleh kepala MA. Kedelapan, disosialisasikan kepada warga MA dan segenap pihak yang berkepentingan. Kesembilan, ditinjau dan dirumuskan kembali secara berkala sesuai dengan perkembangan dan tantangan di masyarakat. ${ }^{29}$

\section{c. Tujuan Madrasah Aliyah}

Madrasah Aliyah merumuskan dan menetapkan tujuan sesuai dengan Peraturan Menteri Pendidikan Nasional Republik Indonesia No 19 Tahun 2007 tentang Standar Pengelolaan Pendidikan serta mengembangkannya, sebagai berikut: pertama, menggambarkan tingkat kualitas yang perlu dicapai dalam jangka menengah (empat tahunan). Kedua, mengacu pada visi, misi, dan tujuan pendidikan nasional serta relevan dengan kebutuhan masyarakat. Ketiga, mengacu pada standar kompetensi lulusan yang sudah ditetapkan oleh Madrasah Aliyah dan Pemerintah. Keempat, mengakomodasi masukan dari berbagai pihak yang berkepentingan termasuk komite Madrasah Aliyah dan

Menengah Dalam: Afnil Guza, SS, Himpunan Permendiknas tentang Standar Pendidikan dan Tenaga Kepndidikan, (Jakarta: AM Asa Mandiri, 2008), hlm. 3

$$
{ }^{29} \text {. Ibid., }
$$

Al-Fikra: Jurnal Ilmiah Keislaman, Vol. 8, No. 2, Juli-Desember 2009

diputuskan oleh rapat dewan pendidik yang dipimpin oleh kepala Madrasah Aliyah. Kelima, disosialisasikan kepada warga Madrasah Aliyah dan segenap pihak yang berkepentingan. ${ }^{30}$

\section{d. Rencana Kerja Madrasah Aliyah}

Madrasah Aliyah membuat rencana kerja jangka menengah yang menggambarkan tujuan yang akan dicapai dalam kurun waktu empat tahun yang berkaitan dengan mutu lulusan yang ingin dicapai dan perbaikan komponen yang mendukung peningkatan mutu lulusan, dan rencana kerja tahunan yang dinyatakan dalam Rencana Kegiatan dan Anggaran Madrasah Aliyah (RKA-MA) dilaksanakan berdasarkan rencana jangka menengah.

Pada pasal 53 pada ayat (1) setiap satuan pendidikan dikelola atas dasar rencana kerja tahunan yang merupakan penjabaran rinci dari rencana kerja jangka menengah satuan pendidikan yang meliputi masa 4 (empat) tahun. ${ }^{31}$ Rencana kerja jangka menengah dan tahunan Madrasah Aliyah itu disetujui rapat dewan pendidik setelah memperhatikan pertimbangan dari komite Madrasah Aliyah dan disahkan berlakunya oleh Depag. Pada Madrasah Aliyah swasta rencana kerja ini disahkan berlakunya oleh penyelenggara Madrasah Aliyah, dituangkan dalam dokumen yang mudah dibaca oleh pihakpihak yang terkait, dan rencana kerja empat tahun dan tahunan disesuaikan dengan persetujuan rapat dewan pendidik dan pertimbangan komite. ${ }^{32}$

Rencana kerja tahunan dijadikan dasar pengelolaan Madrasah Aliyah yang ditunjukkan dengan kemandirian, kemitraan, partisipasi, keterbukaan, dan akuntabilitas. yang memuat ketentuan yang jelas mengenai: 1) kesiswaan; 2) kurikulum dan kegiatan pembelajaran; 3) pendidik dan tenaga kependidikan serta pengembangannya; 4) sarana dan prasarana; 5) keuangan dan pembiayaan; 6) budaya dan lingkungan Madrasah Aliyah; 7) peranserta masyarakat dan kemitraan;

\footnotetext{
30 . Ibid.,

31. Depag, Standar Nasional Pendidikan, hlm. 30

32. Afnil, Himpunan Permendiknas, hlm. 4
} 
Yundri Akhyar, Pengelolaan Pendidikan Madrasah Aliyah ...

8) rencana-rencana kerja lain yang mengarah kepada peningkatan dan pengembangan mutu Madrasah Aliyah. 33

\section{Pelaksanaan Rencana Kerja}

Termasuk dalam kaitan pelaksanaan rencana kerja ini, pedoman Madrasah Aliyah, struktur organisasi, pelaksanaan kegiatan, bidang kesiswaan, bidang kurikulum dan kegiatan pembelajaran, bidang pendidik dan tenaga kependidikan, bidang sarana dan prasarana, budaya dan lingkungan, serta peranserta masyarakat dan kemitraan Madrasah Aliyah tersebut.

\section{a. Pedoman Madrasah Aliyah}

Madrasah Aliyah membuat dan memiliki pedoman yang mengatur berbagai aspek pengelolaan secara tertulis yang mudah dibaca oleh pihak-pihak yang terkait. Pertama, perumusan pedoman MA: mempertimbangkan visi, misi dan tujuan MA; ditinjau dan dirumuskan kembali secara berkala sesuai dengan perkembangan masyarakat. Kedua, pedoman pengelolaan MA meliputi: kurikulum tingkat satuan pendidikan (KTSP); kalender pendidikan/akademik; struktur organisasi MA; pembagian tugas di antara guru; pembagian tugas di antara tenaga kependidikan; peraturan akademik; tata tertib Madrasah Aliyah; kode etik MA; biaya operasional MA.

\section{b. Struktur Organisasi Madrasah Aliyah}

Lampiran Peraturan Menteri Pendidikan Nasional Republik Indonesia No 19 Tahun 2007 tentang Standar Pengelolaan Pendidikan menyebutkan isi struktur organisasi Madrasah Aliyah berpedoman kepada: 1) memasukkan unsur staf administrasi dengan wewenang dan tanggungjawab yang jelas untuk menyelenggarakan administrasi secara optimal; 2) dievaluasi secara berkala untuk melihat efektifitas mekanisme kerja pengelolaan madrasah; 3) diputuskan oleh kepala
Al-Fikra: Jurnal Ilmiah Keislaman, Vol. 8, No. 2, Juli-Desember 2009 MA dengan mempertimbangkan pendapat dari komite Madrasah Aliyah. ${ }^{34}$

\section{c. Pelaksanaan Kegiatan Madrasah Aliyah}

Kegiatan MA sebagaimana diatur di dalam Peraturan Menteri Pendidikan Nasional Republik Indonesia No 19 Tahun 2007 tentang Standar Pengelolaan Pendidikan itu sebagai berikut : pertama, dilaksanakan berdasarkan rencana kerja tahunan. Kedua, dilaksanakan oleh penanggung jawab kegiatan yang didasarkan pada ketersediaan sumber daya yang ada. ${ }^{35}$ Pelaksanaan kegiatan MA yang tidak sesuai dengan rencana yang sudah ditetapkan perlu mendapat persetujuan melalui rapat dewan pendidik dan komite MA. Kemudian kepala MA mempertanggungjawabkan pelaksanaan pengelolaan bidang akademik pada rapat dewan pendidik dan bidang non-akademik pada rapat komite MA dalam bentuk laporan pada akhir tahun ajaran yang disampaikan sebelum penyusunan rencana kerja tahunan berikutnya.

\section{d. Bidang Kesiswaan}

Madrasah Aliyah menyusun dan menetapkan petunjuk pelaksanaan operasional mengenai proses penerimaan peserta didik yang meliputi: pertama, kriteria calon peserta didik MA adalah berasal dari anggota masyarakat yang telah lulus dari SMP/MTs, Paket B atau satuan pendidikan lainnya yang sederajat. Kedua, penerimaan peserta didik MA dilakukan: a) secara obyektif, transparan, dan akuntabel sebagaimana tertuang dalam aturan MA; b) tanpa diskriminasi atas dasar pertimbangan gender, agama, etnis, status sosial, kemampuan ekonomi; c) berdasar kriteria hasil ujian nasional; d) sesuai dengan daya tampung MA. Ketiga, orientasi peserta didik baru yang bersifat akademik dan pengenalan lingkungan tanpa kekerasan dengan pengawasan guru. Keempat madrasah memberikan layanan konseling kepada peserta didik. Kelima, melaksanakan kegiatan ekstra dan
33. Ibid..

\section{4 . Ibid..}

35. Ibid., hlm. 5 
Yundri Akhyar, Pengelolaan Pendidikan Madrasah Aliyah ...

kokurikuler untuk para peserta didik. Keenam, melakukan pembinaan prestasi unggulan, ketujuh, melakukan pelacakan terhadap alumni. ${ }^{36}$

\section{e. Bidang Kurikulum dan Kegiatan Pembelajaran}

Pada pasal 52 bagian "a" menyebutkan bahwa setiap satuan pendidikan harus memiliki pedoman yang Kurikulum tingkat satuan pendidikan dan silabus. ${ }^{37}$ Kurikulum Tingkat Satuan Pendidikan (KTSP) itu diatur dengan tahapan-tahapan sebagai berikut: pertama, Madrasah Aliyah menyusun KTSP. Kedua, penyusunan KTSP memperhatikan Standar Kompetensi Lulusan, Standar Isi, dan peraturan pelaksanaannya. Ketiga, KTSP dikembangkan sesuai dengan kondisi Madrasah Aliyah, potensi atau karakteristik daerah, sosial budaya masyarakat setempat, dan peserta didik. Keempat, kepala MA bertanggungjawab atas tersusunnya KTSP. Kelima, wakil kepala Madrasah Aliyah bidang kurikulum bertanggungjawab atas pelaksanaan penyusunan KTSP. Keenam, Setiap guru bertanggungjawab menyusun silabus setiap mata pelajaran yang diampunya sesuai dengan Standar Isi, Standar Kompetensi Lulusan, dan Panduan Penyusunan KTSP. Ketujuh, dalam penyusunan silabus, guru dapat bekerjasama dengan Kelompok Kerja Guru (KKG), Musyawarah Guru Mata Pelajaran (MGMP), Lembaga Penjamin Mutu Pendidikan (LPMP), atau Perguruan Tinggi Agama. Kedelapan, penyusunan KTSP tingkat MA dipandu juga oleh Kantor Wilayah Departemen Agama Provinsi. 38

\section{f. Bidang Pendidik dan Tenaga Kependidikan}

Pada bagian "d" dan "e" pasal 52 disebutkan pembagian tugas di antara pendidik dan pembagian tugas di antara tenaga kependidikan harus diatur. ${ }^{39}$ Dengan demikian, maka Madrasah Aliyah menyusun program pendayagunaan pendidik dan tenaga kependidikan yang

36 . Ibid..

37. Depag, Standar Nasional Pendidikan, hlm. 29

38 Afnil, Himpunan Permendiknas, hlm. 6

39. Depag, Standar Nasional Pendidikan, hlm. 29
Al-Fikra: Jurnal Ilmiah Keislaman, Vol. 8, No. 2, Juli-Desember 2009

disusun dengan memperhatikan Standar Pendidik dan Tenaga Kependidikan; dikembangkan sesuai dengan kondisi MA, termasuk pembagian tugas, mengatasi bila terjadi kekurangan tenaga, menentukan sistem penghargaan, dan pengembangan profesi bagi setiap pendidik dan tenaga kependidikan serta menerapkannya secara profesional, adil, dan terbuka.

Sedangkan mengenai pengangkatan pendidik dan tenaga kependidikan tambahan dilaksanakan berdasarkan ketentuan yang ditetapkan oleh penyelenggara MA dengan empat pertimbangan sebagai berikut: 1) promosi pendidik dan tenaga kependidikan berdasarkan asas kemanfaatan, kepatutan, dan profesionalisme; 2) pengembangan pendidik dan tenaga kependidikan yang diidentifikasi secara sistematis sesuai dengan aspirasi individu, kebutuhan kurikulum dan sekolah/madrasah; 3) penempatan tenaga kependidikan disesuaikan dengan kebutuhan baik jumlah maupun kualifikasinya dengan menetapkan prioritas; 4) mutasi tenaga kependidikan dari satu posisi ke posisi lain didasarkan pada analisis jabatan dengan diikuti orientasi tugas oleh pimpinan tertinggi sekolah/madrasah yang dilakukan setelah empat tahun, tetapi bisa diperpanjang berdasarkan alasan yang dapat dipertanggungjawabkan, sedangkan untuk tenaga kependidikan tambahan tidak ada mutasi. ${ }^{40}$

Dalam bidang ini juga mendayagunakan kepala MA untuk melaksanakan tugas dan tanggung jawabnya sebagai pimpinan pengelolaan MA dan wakil kepala MA bidang kurikulum melaksanakan tugas dan tanggung jawabnya sebagai pembantu kepala MA dalam mengelola bidang kurikulum, kemudian guru melaksanakan tugas dan tanggungjawabnya sebagai agen pembelajaran yang memotivasi, memfasilitasi, mendidik, membimbing, dan melatih peserta didik sehingga menjadi manusia berkualitas dan mampu mengaktualisasikan potensi kemanusiaannya secara optimum, serta konselor melaksanakan tugas dan tanggung jawabnya dalam memberikan layanan bimbingan dan konseling kepada peserta didik. Pelatih/instruktur melaksanakan tugas dan tanggung jawabnya

40. Afnil, Himpunan Permendiknas, hlm. 6 
Yundri Akhyar, Pengelolaan Pendidikan Madrasah Aliyah ...

memberikan pelatihan teknis kepada peserta didik pada kegiatan pelatihan. Tenaga perpustakaan melaksanakan tugas dan tanggung jawabnya melaksanakan pengelolaan sumber belajar di perpustakaan; Tenaga laboratorium melaksanakan tugas dan tanggung jawabnya membantu guru mengelola kegiatan praktikum di laboratorium. Teknisi sumber belajar melaksanakan tugas dan tanggung jawabnya mempersiapkan, merawat, memperbaiki sarana dan prasarana pembelajaran. Tenaga administrasi melaksanakan tugas dan tanggung jawabnya dalam menyelenggarakan pelayanan administrative. Serta tenaga kebersihan melaksanakan tugas dan tanggung jawabnya dalam memberikan layanan kebersihan lingkungan.

\section{g. Bidang Sarana dan Prasarana}

Setiap Madrasah Aliyah wajib memiliki prasarana yang meliputi lahan, ruang kelas, ruang pimpinan satuan pendidikan, ruang pendidik, ruang tata usaha, ruang perpustakaan, ruang laboratorium, ruang bengkel kerja, ruang unit produksi, ruang kantin, instalasi daya dan jasa, tempat berolahraga, tempat beribadah, tempat bermain, tempat berkreasi, dan ruang/tempat lain yang diperlukan untuk menunjang proses pembelajaran yang teratur dan berkelanjutan.

Program pengelolaan sarana dan prasarana mengacu pada Standar Sarana dan Prasarana dalam hal: pertama, merencanakan, memenuhi dan mendayagunakan sarana dan prasarana pendidikan. Kedua, mengevaluasi dan melakukan pemeliharaan sarana dan prasarana agar tetap berfungsi mendukung proses pendidikan. Ketiga, melengkapi fasilitas pembelajaran pada setiap tingkat kelas di Madrasah Aliyah. Keempat, menyusun skala prioritas pengembangan fasilitas pendidikan sesuai dengan tujuan pendidikan dan kurikulum masing-masing tingkat. Kelima, pemeliharaan semua fasilitas fisik dan peralatan dengan memperhatikan kesehatan dan keamanan lingkungan. ${ }^{41}$

\section{h. Bidang Keuangan dan Pembiayaan}

$$
{ }^{41} \text {. Ibid.,. }
$$

Al-Fikra: Jurnal Ilmiah Keislaman, Vol. 8, No. 2, Juli-Desember 2009

Urusan anggaran untuk pendidikan madrasah pada saat otonomi dicover oleh daerah dan masyarakat sebagaimana pasal 46 ayat $1 \mathrm{UU}$ No 20/2003 Sisdiknas menyebutkan bahwa pendanaan pendidikan menjadi tanggung jawab bersama antara Pemerintah, Pemerintah Daerah, dan masyarakat. ${ }^{42}$ Berdasarkan pada prinsip keadilan, efisiensi, transparansi, dan akuntabilitas publik. ${ }^{43}$ Dengan adanya aturan ini seharusnya diskriminasi anggaran daerah terhadap pendidikan madrasah seharus tidak ada lagi. Sebab sampai saat ini masih terlihat diskriminasi itu masih ada dengan memberikan alokasi dana kepada madrasah tapi dengan jumlah yang tidak sebanding dengan pendidikan umum.

Anggaran pembiayaan Madrasah Aliyah itu terbagi kepada; biaya investasi dan operasional. Dengan demikian dibuat pedoman pengelolaan biaya investasi dan operasional itu mengacu pada standar pembiayaan dalam empat aturan: 1) sumber pemasukan, pengeluaran dan jumlah dana yang dikelola; 2) penyusunan dan pencairan anggaran, serta penggalangan dana di luar dana investasi dan operasional; 3) kewenangan dan tanggungjawab kepala madrasah dalam membelanjakan anggaran pendidikan sesuai dengan peruntukannya; 4) pembukuan semua penerimaan dan pengeluaran serta penggunaan anggaran, untuk dilaporkan kepada komite MA, serta institusi di atasnya. ${ }^{44}$ Biaya investasi dan operasional Madrasah Aliyah diputuskan oleh komite MA dan ditetapkan oleh kepala MA serta mendapatkan persetujuan dari institusi di atasnya. Kemudian disosialisasikan kepada seluruh warga MA untuk menjamin tercapainya pengelolaan dana secara transparan dan akuntabel.

\section{i. Budaya dan Lingkungan Madrasah Aliyah}

Madrasah Aliyah menciptakan suasana, iklim, dan lingkungan pendidikan yang kondusif untuk pembelajaran yang efisien dalam prosedur pelaksanaan sebagai berikut: pertama, berisi prosedur tertulis

42 UU No. 20/2003 Sisdiknas, hlm. 24

${ }^{43}$ Lihat: Ibid. pasal 48 UU No. 20/2003 Sisdiknas

${ }^{44}$. Ibid., hlm. 
Yundri Akhyar, Pengelolaan Pendidikan Madrasah Aliyah ...

mengenai informasi kegiatan penting minimum yang akan dilaksanakan. Kedua, memuat judul, tujuan, lingkup, tanggung jawab dan wewenang, serta penjelasannya. Ketiga, diputuskan oleh kepala MA dalam rapat dewan pendidik.

Selain ketiga poin di atas, MA juga menetapkan pedoman tatatertib seperti pada pasal 52 ayat (1) bagian "g" menjelaskan tata tertib satuan pendidikan, yang minimal meliputi tata tertib pendidik, tenaga kependidikan dan peserta didik, serta penggunaan dan pemeliharaan sarana dan prasarana; ${ }^{45}$ serta adanya petunjuk, peringatan, dan larangan dalam berperilaku di MA dan memberikan sangsi bagi warga yang melanggarnya. ${ }^{46}$ Tata tertib Madrasah Aliyah ditetapkan oleh kepala MA melalui rapat dewan pendidik dengan mempertimbangkan masukan komite Madrasah Aliyah, dan peserta didik.

\section{Kode Etik Peserta Didik}

Kode etik yang mengatur peserta didik memuat norma untuk:

- menjalankan ibadah sesuai dengan aturan agama Islam

- menghormati pendidik dan tenaga kependidikan

- mengikuti proses pembelajaran dengan menjunjung tinggi ketentuan pembelajaran dan mematuhi semua peraturan yang berlaku

- memelihara kerukunan dan kedamaian untuk mewujudkan harmoni sosial di antara teman

- mencintai keluarga, masyarakat, dan menyayangi sesama

- mencintai lingkungan, bangsa, negara dan agama

- menjaga dan memelihara sarana dan prasarana, kebersihan, ketertiban, keamanan, keindahan, dan kenyamanan MA. ${ }^{47}$

Peserta didik dalam menjaga norma pendidikan tersebut perlu mendapat bimbingan dengan keteladanan, pembinaan dengan

\footnotetext{
45. Depag, Standar Nasional Pendidikan, hlm. 29

46. Afnil, Himpunan Permendiknas, hlm. 7

47. Ibid..
}

Al-Fikra: Jurnal Ilmiah Keislaman, Vol. 8, No. 2, Juli-Desember 2009 membangun kemauan, serta pengembangan kreativitas dari pendidik dan tenaga kependidikan.

\section{Kode Etik Guru Dan Tenaga Kependidikan}

Kode etik yang mengatur guru dan tenaga kependidikan memasukkan larangan bagi guru dan tenaga kependidikan, secara perseorangan maupun kolektif, untuk: pertama, menjual buku pelajaran, seragam/bahan pakaian MA, dan/atau perangkat madrasah lainnya baik secara langsung maupun tidak langsung kepada peserta didik. Kedua, memungut biaya dalam memberikan bimbingan belajar atau les kepada peserta didik. Ketiga, memungut biaya dari peserta didik baik secara langsung maupun tidak langsung yang bertentangan dengan peraturan dan undang-undang. Keempat, melakukan sesuatu baik secara langsung maupun tidak langsung yang mencederai integritas hasil Ujian Madrasah Aliyah dan Ujian Nasional.48

Empat kode etik untuk guru dan tenaga kependidikan di atas memang perlu diperhatikan, agar guru dan tenaga kependidikan tetap waspada dan tidak terjebak dalam pelanggaran sebagaimana banyak terjadi pada saat sekarang ini.

\section{j. Peranserta Masyarakat dan Kemitraan Madrasah Aliyah}

Lingkungan di mana madrasah berada, merupakan merupakan masyarakat yang bersifat kompleks, terdiri dari berbagai macam tingkatan masyarakat yang saling melengkapi (overlapping), dan bersifat unik, sebagai akibat latar belakang dimensi budaya yang beraneka ragam. Oleh sebab itu perlu dipertimbangkan betul-betul, dalam memperbaiki dan mempertinggi hubungan kerja sama antara madrasah dengan masyarakat, yaitu dengan melibatkan orang tua, dan masyarakat serta isu-isu yang timbul dan bagaimana menyelesaikan isu-isu tersebut.

Di dalam Lampiran Peraturan Menteri Pendidikan Nasional Republik Indonesia No 19 Tahun 2007 tentang Standar Pengelolaan

48 . Ibid., 
Yundri Akhyar, Pengelolaan Pendidikan Madrasab Alizah ...

Pendidikan oleh Satuan Pendidikan Dasar dan Menengah mengenai Peranserta Masyarakat dan Kemitraan MA, menyebutkan: pertama, Madrasah Aliyah melibatkan warga dan masyarakat pendukung dalam mengelola pendidikan. Kedua, warga Madrasah Aliyah dilibatkan dalam pengelolaan akademik. Ketiga, masyarakat pendukung MA dilibatkan dalam pengelolaan non-akademik. Keempat, keterlibatan peranserta warga MA dan masyarakat dalam pengelolaan dibatasi pada kegiatan tertentu yang ditetapkan. Kelima, setiap Madrasah Aliyah menjalin kemitraan dengan lembaga lain yang relevan, berkaitan dengan input, proses, output, dan pemanfaatan lulusan. Keenam, kemitraan Madrasah Aliyah dilakukan dengan lembaga pemerintah atau non-pemerintah. Ketujuh, kemitraan MA dilakukan minimal dengan perguruan tinggi, MTs, atau yang setara, serta dunia usaha dan dunia industri di lingkungannya. Kedelapan, sistem kemitraan madrasah ditetapkan dengan perjanjian secara tertulis. ${ }^{49}$

Dari delapan point kemitraan tersebut di atas, menunjukkan perlunya dilakukan kemitraan ini agar MA tidak bergerak sendirisendiri tetap berkembang dan bergerak dengan melibatkan lembaga pendidikan atau instansi lain, sehingga betul-betul membawa energi panas bagi kemajuannya dan masyarakat sekitarnya.

\section{Pengawasan dan Evaluasi}

Bahasan yang berkaitan dengan pengawasan dan evaluasi dalam Permendiknas no. 19 tahun 2007 itu dijelakan mengenai; program pengawasan, evaluasi diri, evaluasi dan pengembangan KTSP, evaluasi pendayagunaan pendidik dan tenaga kependidikan, serta akreditasi.

\section{a. Program Pengawasan}

Di Peraturan Menteri Pendidikan Nasional Republik Indonesia No 19 Tahun 2007 tentang Standar Pengelolaan Pendidikan oleh Satuan Pendidikan Dasar dan Menengah itu ada dua belas program pengawasan MA adalah sebagai berikut : pertama, menyusun program

${ }^{49}$ Ibid., hlm. 8
A1-Fikra: Jurnal Ilmiah Keislaman, Vol. 8, No. 2, Juli-Desember 2009

pengawasan secara obyektif, bertanggung jawab dan berkelanjutan. Kedua, penyusunan program pengawasan di madrasah didasarkan pada Standar Nasional Pendidikan. Ketiga, program pengawasan disosialisasikan ke seluruh pendidik dan tenaga kependidikan. Keempat, pengawasan pengelolaan MA meliputi pemantauan, supervisi, evaluasi, pelaporan, dan tindak lanjut hasil pengawasan. Kelima, pemantauan pengelolaan madrasah dilakukan oleh komite madrasah atau bentuk lain dari lembaga perwakilan pihak-pihak yang berkepentingan secara teratur dan berkelanjutan untuk menilai efisiensi, efektivitas, dan akuntabilitas pengelolaan. Keenam, supervisi pengelolaan akademik dilakukan secara teratur dan berkelanjutan oleh kepala MA dan pengawas MA. Ketujuh, guru melaporkan hasil evaluasi dan penilaian sekurang-kurangnya setiap akhir semester yang ditujukan kepada kepala madrasah dan orang tua/wali peserta didik. Kedelapan, tenaga kependidikan melaporkan pelaksanaan teknis dari tugas masingmasing sekurang-kurangnya setiap akhir semester yang ditujukan kepada kepala MA. kepala MA, secara terus menerus melakukan pengawasan pelaksanaan tugas tenaga kependidikan. Kesembilan, kepala sekolah/madrasah melaporkan hasil evaluasi kepada komite sekolah/madrasah dan pihak-pihak lain yang berkepentingan sekurang-kurangnya setiap akhir semester. Kesepuluh, pengawas MA melaporkan hasil pengawasan di madrasah kepada Kantor Departemen Agama Kabupaten/Kota dan pada madrasah yang bersangkutan, setelah dikonfirmasikan pada madrasah terkait. Kesebelas, setiap pihak yang menerima laporan hasil pengawasan menindaklanjuti laporan hasil pengawasan tersebut dalam rangka meningkatkan mutu MA, termasuk memberikan sanksi atas penyimpangan yang ditemukan. Keduabelas, Madrasah mendokumentasikan dan menggunakan hasil pemantauan, supervisi, evaluasi, dan pelaporan serta catatan tindak lanjut untuk memperbaiki kinerja MA, dalam pengelolaan pembelajaran dan pengelolaan secara keseluruhan. ${ }^{50}$

\section{b. Evaluasi Diri}

50. Ibid. hlm. 9 
Yundri Akhyar, Pengelolaan Pendidikan Madrasah Aliyah ...

Dalam Lampiran Peraturan Menteri Pendidikan Nasional Republik Indonesia No 19 Tahun 2007 tentang Standar Pengelolaan Pendidikan oleh Satuan Pendidikan Dasar dan Menengah mengenai evaluasi diri, menyebutkan: pertama, madrasah melakukan evaluasi diri terhadap kinerja MA. Kedua, menetapkan prioritas indikator untuk mengukur, menilai kinerja, dan melakukan perbaikan dalam rangka pelaksanaan Standar Nasional Pendidikan. Ketiga, melaksanakan evaluasi proses pembelajaran secara periodik, sekurang-kurangnya dua kali dalam setahun, pada akhir semester akademik, dan evaluasi program kerja tahunan secara periodik sekurang-kurangnya satu kal dalam setahun, pada akhir tahun anggaran. Keempat, evaluasi diri MA dilakukan secara periodik berdasar pada data dan informasi yang sahih. ${ }^{51}$

\section{c. Evaluasi dan Pengembangan KTSP}

Kurikulum dipahami sebagai seperangkat rencana dan pengaturan mengenai tujuan, isi, dan bahan pelajaran serta cara yang digunakan sebagai pedoman penyelenggaraan kegiatan pembelajaran untuk mencapai tujuan pendidikan tertentu, maka dengan terbitnya Peraturan Pemerintah Nomor 19 Tahun 2005, pemerintah telah menggiring pelaku pendidikan untuk mengimplementasikan kurikulum dalam bentuk kurikulum tingkat satuan pendidikan, yaitu kurikulum operasional yang disusun oleh dan dilaksanakan di setiap Madrasah Aliyah.

Proses evaluasi dan pengembangan KTSP dilaksanakan secara: pertama, komprehensif dan fleksibel dalam mengadaptasi kemajuan ilmu pengetahuan dan teknologi yang mutakhir. Kedua, berkala untuk merespon perubahan kebutuhan peserta didik dan masyarakat, serta perubahan sistem pendidikan, maupun perubahan social. Ketiga, integratif dan monolitik sejalan dengan perubahan tingkat mata pelajaran. Keempat, menyeluruh dengan melibatkan berbagai pihak
Al-Fikra: Jurnal Ilmiah Keislaman, Vol. 8, No. 2, Juli-Desember 2009 meliputi: dewan pendidik, komite madrasah, pemakai lulusan, dan alumni. ${ }^{52}$

Menurut penulis, secara substansial, pemberlakuan Kurikulum Tingkat Satuan Pendidikan (KTSP) lebih kepada mengimplementasikan regulasi yang ada, yaitu PP No. 19/2005. Akan tetapi, esensi isi dan arah pengembangan pembelajaran tetap masih bercirikan tercapainya paket-paket kompetensi (dan bukan pada tuntas tidaknya sebuah subject matter), yaitu:

- Menekankan pada ketercapaian kompetensi siswa baik secara individual maupun klasikal.

- Berorientasi pada hasil belajar (learning outcomes) dan keberagaman.

- Penyampaian dalam pembelajaran menggunakan pendekatan dan metode yang bervariasi.

- Sumber belajar bukan hanya guru, tetapi juga sumber belajar lainnya yang memenuhi unsur edukatif.

- Penilaian menekankan pada proses dan hasil belajar dalam upaya penguasaan atau pencapaian suatu kompetensi.

\section{d. Evaluasi Pendayagunaan Pendidik dan Tenaga Kependidikan}

Adapun evaluasi pendayagunaan pendidik dan tenaga kependidikan adalah dengan ketentuan sebagai berikut : pertama, evaluasi pendayagunaan pendidik dan tenaga kependidikan direncanakan secara komprehensif pada setiap akhir semester dengan mengacu pada Standar Pendidik dan Tenaga Kependidikan. Kedua, evaluasi pendayagunaan pendidik dan tenaga kependidikan meliputi kesesuaian penugasan dengan keahlian, keseimbangan beban kerja, dan kinerja pendidik dan tenaga kependidikan dalam pelaksanaan tugas. ketiga, evaluasi kinerja pendidik harus memperhatikan pencapaian prestasi dan perubahan-perubahan peserta didik. ${ }^{53}$

\section{Ibid.}

53. Ibid 
Yundri Akhyar, Pengelolaan Pendidikan Madrasah Aliyah ...

\section{e. Akreditasi Madrasah Aliyah}

Akreditasi madrasah adalah proses penilaian secara komprehensif terhadap kelayakan dan kinerja satuan dan/atau program pendidikan, yang dilakukan sebagai bentuk akuntabilitas public. Di dalam proses akreditasi, sebuah sekolah/madrasah dievaluasi dalam kaitannya dengan arah dan tujuannya, serta didasarkan kepada keseluruhan kondisi madrasah sebagai sebuah institusi belajar. Walaupun beragam perbedaan dimungkinkan terjadi antar madrasah, tetapi sekolah/madrasah dievaluasi berdasarkan standar tertentu. Standar diharapkan dapat mendorong dan menciptakan suasana kondusif bagi pertumbuhan pendidikan dan memberikan arahan untuk evaluasi diri yang berkelanjutan, serta menyediakan perangsang untuk terus berusaha mencapai mutu yang diharapkan.

Akreditasi merupakan alat regulasi diri (self-regulation) agar madrasah mengenal kekuatan dan kelemahan serta melakukan upaya yang terus menerus untuk meningkatkan kekuatan dan memperbaiki kelemahannya. Dalam hal ini akreditasi memiliki makna proses pendidikan. Di samping itu akreditasi juga merupakan penilaian hasil dalam bentuk sertifikasi formal terhadap kondisi suatu madrasah yang telah memenuhi standar layanan tertentu yang telah ditetapkan oleh pemerintah. Dengan demikian dapat dikatakan bahwa proses akreditasi dalam makna proses adalah penilaian dan pengembangan mutu suatu madrasah secara berkelanjutan. Akreditasi dalam makna hasil menyatakan pengakuan bahwa suatu madrasah telah memenuhi standar kelayakan yang telah ditentukan.

Dalam hal Akreditasi ini ada beberapa tahapan yang perlu dilakukan oleh Madrasah Aliyah : pertama, menyiapkan bahan-bahan yang diperlukan untuk mengikuti akreditasi sesuai dengan peraturan perundang-undangan yang berlaku. Kedua, meningkatkan status akreditasi, dengan menggunakan lembaga akreditasi eksternal yang memiliki legitimasi. Ketiga, Madrasah Aliyah harus terus meningkatkan
Al-Fikra: Jurnal Ilmiah Keislaman, Vol. 8, No. 2, Juli-Desember 2009

kualitas kelembagaannya secara holistik dengan menindaklanjuti saransaran hasil akreditasi. ${ }^{54}$

Ketiga langkah tersebut di atas menunjukkan bahwa Madrasah Aliyah harus betul-betul menyeiapkan secara matang segala perangkat yang diperlukan agar mendapatkan nilai Akreditasi A, sebab tingginya nilai akreditasi madrasah tersebut otomatis sekolah itu sudah atau hampir memenuhi standar yang ditetapkan.

\section{Kepemimpinan Madrasah Aliyah}

Madrasah adalah lembaga yang bersifat kompleks dan unik. Bersifat kompleks karena madrasah sebagai lembaga pendidikan di dalamnya terdapat berbagai dimensi yang satu sama lain saling berkaitan dan saling menentukan. Sedang sifat unik, menunjukkan bahwa madrasah sebagai organisasi memiliki cirri-ciri tertentu yang tidak dimiliki oleh lembaga lain. Cirri-ciri yang menempatkan madrasah memiliki karakter tersendiri, di mana terjadi proses belajarmengajar, tempat terselenggarannya pembinaan kepribadian Islam di kalangan siswa-siswinya. ${ }^{55}$

Karena sifatnya yang kompleks dan unik tersebutlah, madrasah sebagai suatu lembaga pendidikan memerlukan tingkat koordinasi yang tinggi. Oleh sebab itu, maka kepemimpinan Madrasah Aliyah dipegang oleh satu orang kepela dan tiga orang wakil sebagai pembantu kepala MA dalam menjalankan tugasnya. Ada orang mengatakan "Keberhasilan madrasah adalah keberhasilan kepala madrasah

\section{a. kepala madrasah}

Pada pasal 50 ayat (1) dijelaskan setiap satuan pendidikan dipimpin oleh seorang kepala satuan sebagai penanggung jawab pengelolaan pendidikan. Dengan demikan, setiap MA dipimpin oleh

54. Ibid., hlm

55. Wahjosumidjo, Kepemimpinan Kepela Sekolah, Tinjanan Teori dan Permasalahannya, (Jakarta, RajaGrafindo Persada, 2005), hlm. 81 
Yundri Akhyar, Pengelolaan Pendidikan Madrasah Aliyah ...

seorang kepala dengan kreteria yang berdasarkan ketentuan dalam standar pendidik dan tenaga kependidikan. ${ }^{56}$

Di dalam Peraturan Menteri Pendidikan Nasional Republik Indonesia No 19 Tahun 2007 tentang Standar Pengelolaan Pendidikan menyebutkan ada 18 tugas dan fungsi kepala Madaras Aliyah, sebagai berikut: pertama, menjabarkan visi ke dalam misi target mutu; kedua, merumuskan tujuan dan target mutu yang akan dicapai; ketiga, menganalisis tantangan, peluang, kekuatan, dan kelemahan madrasah; keempat, membuat rencana kerja strategis dan rencana kerja tahunan untuk pelaksanaan peningkatan mutu; kelima, bertanggung jawab dalam membuat keputusan anggaran sekolah/madrasah; keenam, melibatkan guru, komite sekolah dalam pengambilan keputusan penting sekolah/madrasah. Dalam hal sekolah/madrasah swasta, pengambilan keputusan tersebut harus melibatkan penyelenggara MA; ketujuh, berkomunikasi untuk menciptakan dukungan intensif dari orang tua peserta didik dan masyarakat; kedelapan menjaga dan meningkatkan motivasi kerja pendidik dan tenaga kependidikan dengan menggunakan sistem pemberian penghargaan atas prestasi dan sangsi atas pelanggaran peraturan dan kode etik; kesembilan, menciptakan lingkungan pembelajaran yang efektif bagi peserta didik; kesepuluh, bertanggung jawab atas perencanaan partisipatif mengenai pelaksanaan kurikulum; kesebelas, melaksanakan dan merumuskan program supervisi, serta memanfaatkan hasil supervisi untuk meningkatkan kinerja sekolah/madrasah; keduabelas, meningkatkan mutu pendidikan; ketigabelas, memberi teladan dan menjaga nama baik lembaga, profesi, dan kedudukan sesuai dengan kepercayaan yang diberikan kepadanya; keempatbelas, memfasilitasi pengembangan, penyebarluasan, dan pelaksanaan visi pembelajaran yang dikomunikasikan dengan baik dan didukung oleh komunitas sekolah/madrasah; kelimabelas, membantu, membina, dan mempertahankan lingkungan sekolah/madrasah dan program pembelajaran yang kondusif bagi proses belajar peserta didik dan pertumbuhan profesional para guru dan tenaga kependidikan;

56. Depag, Standar Nasional Pendidikan, hlm. 28
A1-Fikra: Jurnal Ilmiah Keislaman, Vol. 8, No. 2, Juli-Desember 2009

keenambelas, menjamin manajemen organisasi dan pengoperasian sumber daya sekolah/madrasah untuk menciptakan lingkungan belajar yang aman, sehat, efisien, dan efektif; ketujubbelas, menjalin kerja sama dengan orang tua peserta didik dan masyarakat, dan komite madrasah menanggapi kepentingan dan kebutuhan komunitas yang beragam, dan memobilisasi sumber daya masyarakat; kedelapanbelas, memberi contoh/teladan/tindakan yang bertanggung jawab. ${ }^{57}$

Peraturan Mendiknas Nomor 13 Tahun 2007 tertanggal 17 April 2007 menetapkan Standar Kepala Madrasah sebagai salah satu standar ketenagaan di antara delapan standar yang harus ditetapkan untuk mewujudkan Standar Nasional Pendidikan kita yang bermutu. Untuk mendukung Standar Nasional Pendidikan ini, menurut Permendiknas tersebut seseorang yang akan diangkat menjadi kepala sekolah wajib memenuhi standar kepala sekolah / madrasah yang berlaku nasional. Standar Kepala Sekolah dimaksud adalah sebagaimana tercantum pada lampiran peraturan menteri dimaksud, yang meliputi Standar Kualifikasi dan Standar Kompetensi.

Adapun Standar Kualifikasi dimaksud meliputi: pertama, kualifikasi Umum, yaitu: (a) Pendidikan Minimum Sarjana (S-1) atau Diploma IV (dalam draft semula diutamakan S-2); (b) Berusia setinggi-tingginya 56 tahun saat diangkat sebagai kepala sekolah; (c) Pengalaman mengajar minimal 5 tahun menurut jenjang sekolahnya (d) Pangkat minimal III/c bagi PNS. Kedua, kualifikasi Khusus menyangkut: (a) Berstatus sebagai guru sesuai jenjang mana akan menjadi kepala sekolah; (b) Mempunyai sertifikat pendidik sebagai guru sesuai jenjangnya; (c) Mempunyai sertifikat kepala sekolah sesuai jenjangnya yang diterbitkan oleh lembaga yang ditetapkan Pemerintah..$^{58}$ Berkenaan dengan Standar Kompetensi, seseorang dapat diangkat sebagai kepala madrasah jika dia memiliki kompetensikompetensi sebagai berikut: (a) Kompetensi kepribadian; (b)

57. Afnil, Himpunan Permendiknas, hlm. 10

58 Peraturan Mendiknas Nomor 13 Tahun 2007 tentang Standar Kepala Sekolah / Madrasah. Dalam: Afnil, Himpunan Permendiknas, hlm. 373 312 
Yundri Akhyar, Pengelolaan Pendidikan Madrasah Aliyah ...

Kompetensi Manajerial; (c) Kompetensi Kewirausahaan (d)

Kompetensi Supervisi; (e) Kompetensi Sosial. ${ }^{59}$

Dilihat dari perspektif peningkatan mutu input pendidikan Permen ini merupakan suatu kemajuan positif dalam upaya mencari dan menetapkan figur pengelola sekolah yang bermutu. Namun dalam rangka profesionalisasi jabatan kepala madrasah menuju terwujudnya kepala madrasah yang mampu mengemban dan mengembangkan tugas dan fungsinya terlihat masih belum sepenuhnya akan dapat diwujudkan. Kepala madrasah yang berhasil apabila mereka memahami keberadaan madrasah sebagai suatu lembaga yang kompleks dan unik, serta mampu melaksanakan peranan kepala madrasah sebagai seorang yang diberi tanggung jawab untuk memimpin madrasah tersebut.

\section{b. wakil kepala madrasah}

Pada ayat (2) pasal 50 disebutkan bahwa dalam melaksanakan tugasnya kepala MA dibantu minimal oleh tiga wakil kepala satuan pendidikan yang masing-masing secara berturut-turut membidangi akademik, sarana dan prasarana, serta kesiswaan. Dengan demikian, Kepala MA dapat mendelegasikan sebagian tugas dan kewenangan kepada wakil kepala sesuai dengan bidangnya. ${ }^{60}$ Wakil kepala MA ini dipilih oleh dewan pendidik, dan proses pengangkatan serta keputusannya, dilaporkan secara tertulis oleh kepala MA kepada institusi di atasnya. Dalam hal MA swasta, institusi dimaksud adalah penyelenggara MA.

Dari ketentuan di atas dikatahui bahwa wakil kepala MA terdiri dari tiga orang dengan bidang-bidang tertentu. Hal ini berbeda yang dengan realita saat ini di mana kepala MA masih memiliki wakil satu orang saja apalagi di MA swasta.

\section{Sistem Informasi Manajemen}

${ }^{59}$ Afnil, Himpunan Permendiknas, hlm. 374

60. Ibid.,hlm. 12
A1-Fikra: Jurnal Ilmiah Keislaman, Vol. 8, No. 2, Juli-Desember 2009

Ketentuan sistem informasi manajemen MA di dalam Lampiran Peraturan Menteri Pendidikan Nasional Republik Indonesia No 19 Tahun 2007 tentang Standar Pengelolaan Pendidikan oleh Satuan Pendidikan Dasar dan Menengah, diatur sebagai berikut: pertama, MA mengelola sistem informasi manajemen yang memadai untuk mendukung administrasi pendidikan yang efektif, efisien dan akuntabel. Kedua, menyediakan fasilitas informasi yang efesien, efektif dan mudah diakses; ketiga, menugaskan seorang guru atau tenaga kependidikan untuk melayani permintaan informasi maupun pemberian informasi atau pengaduan dari masyarakat berkaitan dengan pengelolaan baik secara lisan maupun tertulis dan semuanya direkam dan didokumentasikan. Keempat, melaporkan data informasi MA yang telah terdokumentasikan kepada Depag. ${ }^{61}$

Selain hal di atas diperlukan juga untuk mejaga komunikasi di lingkungan madrasah dengan dilaksanakan secara efisien dan efektif, agar madrasah betul-betul bisa menjadi lembaga pendidikan yang disenangi dan lengket di hati masyarakat.

Sekarang sudah saatnya seluruh madrasah memiliki blog tersendiri diinternet, sehingga warga masyarakat yang ingin mengetahui keadaan madrasah tersebut mereka bisa langsung mengaksesnya. Dalam blog itu, sebaiknya juga dicantumkan segala yang berkaitan dengan madrasah tersebut.

\section{Kesimpulan}

Dari pembahasan di atas dapat disimpulkan bahwa pengelolaan madrasah menurut Peraturan Menteri Pendidikan Nasional No. 19 tahun 2007 tentang Standar Pengelolaan Pendidikan oleh Satuan Pendidikan Dasar dan Menengah adalah sebagai berikut: pertama, pelaksanaan program Madrasah Aliyah harus dilihatkan dengan kemandirian, kemitraan, partisipasi, keterbukaan, dan akuntabilitas yang jelas dan terukur baik mengenai kurikulum, kesiswaan, sarana dan prasarana dan pembiayaan MA. Kedua, Pendanaan pendidikan MA menjadi tanggung jawab bersama antara Pemerintah, Pemerintah

\footnotetext{
61. Ibid.
} 
Yundri Akhyar, Pengelolaan Pendidikan Madrasah Aliyah ...

Daerah, dan masyarakat dengan ketentuan yang diatur. ketiga, murid, guru dan tenaga kepedidikan termasuk pimpinan memiliki kode etik harus betul-betul diindahkan yang antaranya adalah guru dan tenaga kepedidikan tidak boleh baginya memjual buku, seragam/bahan pakaian MA, dan/atau perangkat lainnya baik secara langsung maupun tidak langsung kepada peserta didik. kemudian tidak boleh memungut biaya dalam bentu apapun termasuk biaya les. Hal ini perlu dicamkan bagi guru dan tenaga kepedidikan karena masih banyak madrasah yang belum mengindahkan kode etik ini. keempat, diperlukan supervisi, evaluasi, guna untuk memperbaiki kinerja, dalam pengelolaan pembelajaran dan pengelolaan Madrasah Aliyah secara keseluruhan, sebab tanpa pengawasan dan evalausi yang berkelanjutan akan sulit mengikuti tujuan pendidikan MA yang dinginkan. Kelima,Madrasah Aliyah dipimpin satu orang kepala dan tiga orang wakil. Wakil bidang kurikulum, bidang kesiswaan dan bidang sarana-prasarana. Dengan demikan Madrasah yang selama ini hanya memliki satu orang wakil kepala harus menambah dua orang lagi agar terpenuhi satndar ini. Keenam, akses imformasi di madrasah terbuka dan transfaran dengan menugaskan seorang guru atau tenaga kependidikan untuk melayani permintaan informasi maupun pemberian informasi atau pengaduan dari masyarakat berkaitan dengan pengelolaan baik secara lisan maupun tertulis.

\section{Bibliagrafi}

Al-Jumbulati, Ali. Perbandingan Pendidikan Islam (Jakarta : RajaGrafindo Persada, 1994)

Depag RI, Pendidikan Islam dan Pendidikan Nasional, Paradigma Baru (Jakarta : Dirjen Binbaga, 2005

Fadjar, Malik. Madrasah dan Tantangan Modernitas (Bandung : Mizan, 1998)

Abdullah, Aly Mustafa. Sejarah Pendidikan Islam di Indonesia ( Bandung : Pustaka Setia, 1997)
Al-Fikra: Jurnal Ilmiah Keislaman, Vol. 8, No. 2, Juli-Desember 2009

Depag, RI. Peraturan Pemerintah No. 19 tahun 2005 tentang Standar Nasional Pendidikan, (Jakarta: Mapenda Islam, 2005)

Depag RI, Sejarah Pendidikan Islam di Indonesia (Jakarta : Dirjen Binbaga, 1986)

Karim, Rusli. Pendidikan Islam di Indonesia dalam Transformasi Sosial Budaya, (Yogyakarta: Tiara Wacana, 1991)

Luwis, Abu, al-Yusu 'i, al-Munjid Fi al-Lughah Wa al-Mujid Fi al-'Alam (Bairut : Dar al Musyriq, 1998)

Muhaimin, Abd Mujib, Pemikiran Pendidikan Islam (Bandung : Trigenda Karya, 1993)

Maksum, Madrasah Sejarah \& Perkembangannya (Jakarta : Logos Wacana Ilmu, 1999)

Nakosteen, Mehdi. Konstribusi Islam atas Dunia Intelektual Barat Deskripsi Analisis Abad Keemasan Islam ( Surabaya, Risalah Gusti, Edisi Indonesia, 1996)

Peraturan Menteri Pendidikan Nasional Republik Indonesia No 19 Tahun 2007 tentang Standar Pengelolaan Pendidikan oleh Satuan Pendidikan Dasar dan Menengah. Dalam: Afnil Guza, SS, Himpunan Permendiknas tentang Standar Pendidikan dan Tenaga Kepndidikan, (Jakarta: AM Asa Mandiri, 2008)

Peraturan Mendiknas Nomor 13 Tahun 2007 tentang Standar Kepala Sekolah / Madrasah. Dalam: Afnil Guza, SS, Himpunan Permendiknas tentang Standar Pendidikan dan Tenaga Kepndidikan, (Jakarta: AM Asa Mandiri, 2008)

Tilaar, Paradigma Baru Pendidikan Nasional, (Jakarta, Rineka Cipta, 2004)

Undang-Undang Nomor 20 Tahun 2003 tentang Sistem Pendidikan, Nasional, (Bandung: Fokus Media, 2006)

Wahjosumidjo, Kepemimpinan Kepela Sekolah, Tinjanan Teori dan Permasalahannya, (Jakarta, RajaGrafindo Persada, 2005) 